\title{
Detection of Bovine Herpesvirus 1 and Bovine Viral Diarrhea Virus Specific Antibodies in Individual, Bulk Tank Milk and Serum Samples of Vaccinated Cattle in Different Provinces of Egypt
}

\section{Adel Abdel-Azeem Fayed ${ }^{1}$, Mounir Mohamed Abdel-Halim ${ }^{1}$, Nabila Shaker Degheidy ${ }^{2}$, Mohamed Karam EL-Bayoumy ${ }^{3}$ and Alaa Abdel-moneim Ghazy ${ }^{3}$}

${ }^{1}$ Department of Infectious Diseases, Faculty of Veterinary Medicine, Cairo University, Giza, Egypt

${ }^{2}$ College of Sciences, Taif University, Jedda, KSA

${ }^{3}$ Department of Parasitology and Animal Diseases, National Research Center, Giza, Egypt

Correspondence should be addressed to: Alaa Abdel-moneim Ghazy; aaghazy7@hotmail.com

Received 19 February 2013; Accepted 26 March 2013; Published 26 May 2013

Academic Editor: Mehmet Kale

Copyright (C) 2013 Adel Abdel-Azeem Fayed, Mounir Mohamed Abdel-Halim, Nabila Shaker Degheidy, Mohamed Karam EL-Bayoumy and Alaa Abdel-moneim Ghazy. Distributed under Creative Commons CC-BY 3.0

\begin{abstract}
From three commercial Friesian-Holstein dairy herds located in three different provinces of Egypt "El-Fayoum, EL-Ismailia and EL-Beheira" adopted a number of different vaccination strategies, a total of 183 individual blood samples, individual pooled milk samples collected on the same occasion from the same animal and 23 Bulk Tank Milk (BTM) samples were tested and evaluated for about a year to monitor the immune status of vaccinated cattle against bovine herpesvirus 1 (BHV1) and Bovine Viral Diarrhea (BVD) viruses. All samples were subjected to "BHV1" gB monoclonal Antibody Test Kit (IBRgB test kit "IDEXX Laboratories"), indirect Enzyme-linked immunosorbent assay (ELISA) test for the detection of specific antibodies against (Abu Hammad strain) of BHV1and (Iman strain) of BVD Virus. For investigation and evaluation of vaccination program against BHV1 and BVD viruses, results revealed a high significant correlation and regression coefficient obtained between individual serum and milk titers. Individual milk and BTM samples permit an adequate determination of immune status of the herd for large scale epizotiological studies indicating if Herd Protection level (HPL) is sufficient or not. Both "Pneumo 3" (Veterinary Serum and Vaccine Research-Cairo-Egypt) and "Cattle Master 4" (Pfizer) vaccines were found to be highly effective in producing immune response against BHV1 and BVD viruses. High regression, correlation coefficient and F test significance between IBRgB blocking ELISA and BHV1 indirect ELISA in serum and milk samples were recognized.
\end{abstract}

Keywords: BHV-1, BVD, milk, ELISA, vaccine.

Cite this Article as: Adel Abdel-Azeem Fayed, Mounir Mohamed Abdel-Halim, Nabila Shaker Degheidy, Mohamed Karam EL-Bayoumy and Alaa Abdel-moneim Ghazy (2013), "Detection of Bovine Herpesvirus 1 and Bovine Viral Diarrhea Virus Specific Antibodies in Individual, Bulk Tank Milk and Serum Samples of Vaccinated Cattle in Different Provinces of Egypt," International Journal of Veterinary Medicine: Research \& Reports, Vol. 2013 (2013), Article ID 516614, DOI: 10.5171/2013.516614 


\section{Introduction}

Infectious bovine rhinotracheitis (IBR) is a highly contagious infectious disease that is caused by bovine herpesvirus 1 (BHV1). Apart from respiratory disease, this virus can cause other clinical syndromes such as infectious pustular vulvovaginitis or balanoposthitis, conjunctivitis, encephalitis and generalized systemic infections Gibbs and Rweyemamu (1977), Straub (1991), Ata et al (2006), Nuotio et al (2007) and Straub (1991). In adult cows infection is associated with a severe and prolonged decrease in milk yield, reduced fertility and abortions, many infections run with a subclinical course Rola et al (2005).

If the success of a virus is measured by its ability to spread, cause disease and still persist within a population without being discovered, pestiviruses are perhaps the most successful of all bovine viruses Sandvik (1999), Mohamed et al (2005) and Kale et al (2006). In most countries, large parts of the bovine population have been infected with one or more of them, which usually have been referred to as bovine viral diarrhea virus (BVD virus) Baker (1987) and Kale et al (2011).

While blood samples are usually obtained for antibody detection, milk could be a useful alternative, collection of milk is non invasive and its testing would thus be an easier and more acceptable means than blood sampling for surveys in many situations, Armstrong (1997). Milk antibody testing therefore provides farmers and their veterinary surgeons with a potentially very useful and inexpensive method of initiating disease investigations and monitoring the presence of common endemic infections in the herd. The noninvasive method of sampling also readily lends itself to use in research projects and epidemiological surveys, Pritchard et al (2002) and Abd El-Razik et al (2007).

It has proved possible to identify immune responses in milk against various virus diseases of cattle. Dhenninm et al (1979) showed that neutralizing antibodies could be detected all year round in milk from cows vaccinated annually against Foot and
Mouth disease virus (FMDV). used ELISA to demonstrate responses against Bovine Viral Diarrhea (BVD) virus in both individual and bulk tank milk samples, Bulk milk was a suitable substrate for BVD virus monitoring of herds vaccinated with the inactivated BVD vaccine Niskanen et al (1991) and Alvarez et al (2012). Working with Bovine Respiratory Syncytial (BRS) virus, Elvander et al (1995) found that there was strong correlation in ELISA between milk and serum titers but the level of antibody was lower in milk. Equivalent test sensitivity can be achieved by using different cut-off values or different test dilutions Pritchard et al (2002).

Enzyme-linked immunosorbent assays (ELISAs) are versatile diagnostic methods which can be designed to detect almost any immunoreactive molecule. ELISA for antibody detection is a fast inexpensive and simple method for screening large number of test samples; using this technique on pooled samples (e.g. bulk tank milk samples), the conditions for a low-cost monitoring program are satisfied Nylin et al (2000). For BVD virus serology, they have become popular for several reasons, they are independent of cell cultures, they can easily be applied for mass screening, test result can be read in few hours and reliable results can be obtained with milk as test material, for BVD virus serology they have become popular and reliable results can be obtained with milk as test material Niskanen et al (1989).

Bulk milk tests provide a good starting point for differential diagnosis, in addition to their value for serological monitoring, it is envisaged that veterinary practices could record the information from bulk milk tests and incorporate it into preventive medicine programs, particularly in relation to purchased animals. Regular testing of bulk milk samples every few months provides a simple low cost method of confirming continuing freedom from infection in known disease-free herds; including those at potential risk of introducing new infection Zadnik et al (2001). The present work was carried out to:- 
1- Investigate and evaluate the vaccination program in some dairy farms by identifying antibody responses against BHV1 and BVD viruses in individual milk and serum to monitor the immune status of vaccinated cattle.

2- Study the ability of using bulk tank milk to monitor and evaluate Herd Protection Level (HPL) against BHV1 and BVD virus diseases.

\section{Materials and Methods}

\section{Samples}

In the present study three commercial "Friesian-Holstein" dairy farms ("10" animals at different milking season from each farm) in three different provinces in Egypt at different governorates were investigated as follow:

Herd " $A$ " at "El-fayoum province" impaired a total of "1500" dairy cattle.

Herd " $B$ " at "EL-Ismailia province" impaired a total of "600" dairy cattle.

Herd "C" at "EL-Beheira province", impaired a total of "600" dairy cattle.

Fifty five, 66 and 62 individual pooled milk and blood samples were collected on the same occasion from 30 animals (10 animals representing each herd) through 51, 41 and 54 weeks from herds A, B and C respectively. Eight, 7 and 8 BTM samples representing all dairy animals in the farm were collected from herds A, B and C respectively. To control BHV1, BVD, Parainfluenza virus type 3 (PI3) and Bovine respiratory syncytial (BRS) viruses each dam at herd " $A$ " and "B" was vaccinated two weeks before birth, and then every six months with "pneumo 3" (Veterinary Serum and Vaccine Research-Cairo-Egypt) which contain specific inactivated strains of BHV1, BVD, PI3 and BRSV. Each animal got the vaccine according to its birth date. While all animals at herd " $\mathrm{C}$ " were vaccinated twice annually with "Cattle Master 4" vaccine (Pfizer) which contain a freeze-dried preparation of temperature specific mutant strains of BHV1 and PI3 viruses and modified live BRSV plus a liquid adjuvented preparation of inactivated cytopathic and noncytopathic BVD virus strains.

Herd management in the three commercial dairy farms were considered good, milking machines were functioning adequately and all dairy animals were grown up from heifers' borne in the same farm.

Samples were subjected to:

- "BHV1" gB monoclonal Antibody Test Kit HerdChek IBRgB IDEXX Laboratories Scandinavia $A B$ for detection of glycoprotein B of BHV1 virus

- Indirect ELISA test for detection of specific antibodies to local vaccine strain (Abu Hammad strain) of BHV1.

- Indirect ELISA test for detection of specific antibodies to local vaccine strain (Iman strain) of BVD VIRUS.

\section{Blood Samples:}

Ten milliliters (ml) were collected by puncture of the tail vein using sterile needle for each animal. Flew of blood were allowed in a screw capped sterile tubes. Tubes were labeled and left for half an hour at room temperature then it kept in $4^{\circ} \mathrm{C}$ in a horizontal position to separate the largest possible amount of serum. Within 24 hours, blood samples were centrifuged, and the serum was harvested and stored at $-80^{\circ} \mathrm{C}$. Edwards et al (1986).

\section{Milk Samples:}

Whole milk samples (25ml) were centrifuged for 10 minutes $3000 \mathrm{xg}$ at $4^{\circ} \mathrm{C}$ in cooling centrifuge Niskanen et al (1991) skim milk (from underneath the fat layer) were collected.

\section{Virus System Used:}

BHV1 Virus: Abu Hammad strain (107.5 TCID50/ml) "central lab for control of veterinary biologics, Cairo, Egypt". 
BVD Virus: Iman strain (106.5 TCID50/ml) "central lab for control of veterinary biologics, Cairo, Egypt".

\section{Sera}

Newborn calf serum (NCS) "Selborn Biological services, Tasmania, Australia"

Reference hyperimmune sera against BHV-1 "central lab for control of veterinary biologics, Cairo, Egypt".

Reference hyperimmune sera against BVD "central lab for control of veterinary biologics, Cairo, Egypt".

\section{Vaccines:}

Pneumo 3 (Veterinary Serum and Vaccine Research-Cairo-Egypt): specific binary ethylenimine (BEI) inactivated, aluminum hydroxide adjuvanted strains of BHV1 (Abou Hammad strain), BVD (Iman strain), PI3 (strain 45) and BRSV (strain 375L).

Cattle Master 4 (Pfizer): freeze-dried preparation of temperature-specific mutant strains of BHV1 and PI3 viruses and modified-live BRSV plus a liquid Aluminum hydroxide adjuvanted BVD preparation of inactivated cytopathic and noncytopathic BVD virus strains.

\section{BHV1 and BVD Indirect ELISA:}

Virus Propagation and Adaptation: All reference viruses were initially propagated for three successive passages in Madin Darby bovine kidney (MDBK) cell line according to Edwards et al (1983).

BHV1 and BVD Virus Titration: Virus titration was conducted using infectivity method according to Mohanty and Lillie (1965). The titer of the virus was expressed as $\log 10 \mathrm{TCID}_{50} / \mathrm{ml}$ using the formula of Reed and Muench (1938).

BHV1 Antigen Preparation: It was carried out by some laboratory modification for the method of Florent and Marneffe (1986): Antigens were prepared from viruses grown in secondary cultures of MDBK cells in a serum free maintenance medium. After culture had inoculated with viruses it was incubated at $37^{\circ} \mathrm{C}$ until the cytopathic effect (CPE) reached 50\%. Then cultures were frozen at $-20^{\circ} \mathrm{C}$. After thawing, cells and supernatant fluid were harvested and centrifuged at $100,000 \mathrm{X} \mathrm{g}$ for $1 \mathrm{~h}$ at $4^{\circ} \mathrm{C}$. The resulting pellet was resuspended to a $40 \mathrm{X}$ concentration in phosphate buffered saline (PBS) and sonicated to disperse aggregates. Finally antigen preparations were clarified by centrifugation at $3000 \mathrm{X} \mathrm{g}$ for 20 minutes and stored at $-20^{\circ} \mathrm{C}$. A control ELISA antigen was prepared in a similar manner from non-infected MDBK cells.

BVD Antigen Preparation: It was carried out by some laboratory modification for the method of Lecmote et al (1990), Entrican et al (1995), Kramps et al (1999) and Beaudeau et al (2001):-

MDBK cells were grown in two Roux bottles and washed three times with Eagle's media. The cells in the first bottle were then inoculated with $2 \mathrm{ml}$ of virus after discharging the growth media. This bottle was considered as a positive control antigen. The second bottle was left without inoculation as a negative control antigen from non-infected normal cell culture of MDBK.

The two bottles were incubated at $37^{\circ} \mathrm{C}$ for one hour for adsorption of the virus and the maintenance media was added. When the CPE reached $70-80 \%$ in the inoculated bottle, the two bottles were kept at $-80^{\circ} \mathrm{C}$ after which freezing and thawing was performed three times to the virus extract. After thawing, Triton X-100 was added to the resulting cellular lysate to a final concentration of $0.01 \% \quad(\mathrm{v} / \mathrm{v})$ and incubated at $37^{\circ} \mathrm{C}$ for $1 \mathrm{~h}$. The Triton $\mathrm{X}-100$ inactivated and non-infectious antigen preparation, confirmed by virus isolation test, clarified by centrifugation at $1000 \mathrm{xg}$ (10 min) and used in the ELISA at an optimal dilution as determined by checkerboard titration.

BHV-1 and BVD ELISA Procedures: The indirect ELISA was carried out by some laboratory modification for the method of 
Florent and Marneffe (1986), Wellenberg et al (1998) and Nylin et al (2000) for BHV-1 and Durham and Hassard (1990), Lecmote et al (1990) and Beaudeau et al (2001) for BVD as follows:

Checkerboard titrations were performed with $100 \mu$ volumes of antigen, serum and conjugate to determine optimal dilutions. PBS containing $0.05 \%$ Tween 20 was used for washing and dilutions.

1 - Coating: ELISA plates (96 flat bottom wells) were coated with target antigen by adding $100 \mu$ l of diluted antigen in carbonate bicarbonate buffer (The best dilution was1:900 for BHV-1 \& 1:8 for BVD). Plates were then incubated at $4^{\circ} \mathrm{C}$ overnight, after that the plate's contents were decanted and the plates were washed three times with the washing buffer, and dried by tapping it upside down on a filter paper.

2 - Blocking: The coated plates were blocked by adding $100 \mu$ l of blocking buffer ( $5 \%$ skimmed milk) per well and incubated for 1 hour at $37^{\circ} \mathrm{C}$, then the contents were decanted, the plate washed 5 times and dried as before.

3 - Serum Dilutions: To the coated plates, test serum and skimmed milk, diluted $1 / 50$ \& 1/1 respectively in PBS-tween, were added to positive and control antigen-coated wells. Each sample was run in duplicates, including the control positive and negative sera, as well as, the blank control. After incubation for $1 \mathrm{~h}$ at $37^{\circ} \mathrm{C}$ plates were emptied, rinsed and dried four times.

4 - Addition of the Conjugate: $100 \mu \mathrm{l}$ Peroxidase-labelled rabbit anti-bovine IgG conjugate diluted $1 / 20000$ in PBSTween was added to each well. Plates were incubated for 1 hour at $37^{\circ} \mathrm{C}$ then emptied, rinsed and dried five times.

5 - Addition of the Substrate: Enzyme substrate "O-Phenylenediamine" (OPD) was added to the plate and, incubated in dark place for 15 minutes, a brownish coloration indicating positive reaction was developed.
6 - Addition of Stopping Solution: The reaction was then stopped by adding $25 \mu \mathrm{l}$ per well of $1.25 \mathrm{M}$ of sulphoric acid and the plate was read using ELISA reader at $492 \mathrm{~nm}$.

7 - Interpretation of the Results: Results were expressed according to the following formula:

(mean $O D^{*}$ of sample - mean OD of $\mathrm{NCS}^{* *}$ / mean OD of PCS ${ }^{* * *}$ - mean OD of NCS) x 100

\section{* Optic Density \\ **Negative Control Serum \\ ***Positive Control Serum}

To assess the cut-off level in the BHV1 and BVD indirect ELISAs, the mean ELISA percentage for all negative serum samples and the standard deviation were determined. The calculated cut-off value for BHV1 (mean value plus 2 times the standard deviation) was $35 \%$ and (twice the mean OD for the negative control wells) $40 \%$ for BVD.

\section{Statistical Analysis}

Data were analyzed using a computer statistical package (SPSS for windows, Guide for personal computers, Release 6.1.3, Microsoft company, USA, 1993); Categorical data were analyzed by the same computer program using F-test. Data were presented as mean, standard error, linear regression and correlation coefficient.

\section{Results}

\section{$\underline{I B R g B:}$}

BHV1 blocking percent of individual serum, milk and BTM samples resulting from systemic vaccination in the three farms using IBRgB test kit is presented in Table (1) and illustrated in Figures (1) and (2), Regression, correlation coefficient and $\mathrm{F}$ test significance between IBRgB antibodies blocking percent in individual serum and corresponding milk samples are presented in Figure (3). 
Table (1): BHV1 Blocking\% in Individual Serum, Milk and BTM Samples Collected from the Three Farms as Assessed by ELISA

\begin{tabular}{|l|l|l|l|l|l|}
\hline Farm & Serum (S) & SE & Individual milk (M) & SE & B.T.M. \\
\hline A & $97.5 \%$ & 0.05 & $94.8 \%$ & 0.44 & $94.9 \%$ \\
\hline B & $97.3 \%$ & 0.18 & $87.0 \%$ & 1.53 & $95.3 \%$ \\
\hline C & $97.0 \%$ & 0.28 & $90.0 \%$ & 1 & $96.1 \%$ \\
\hline
\end{tabular}

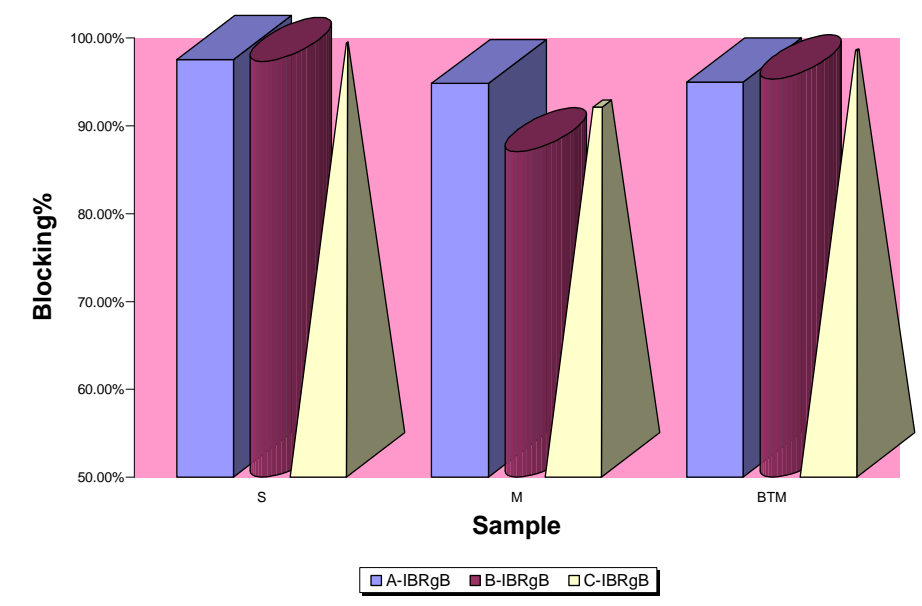

Fig. (1): Mean BHV1 Blocking Percent in Serum, Milk and BTM Collected from the Three Farms, as Assessed by IBR Gb Test Kit

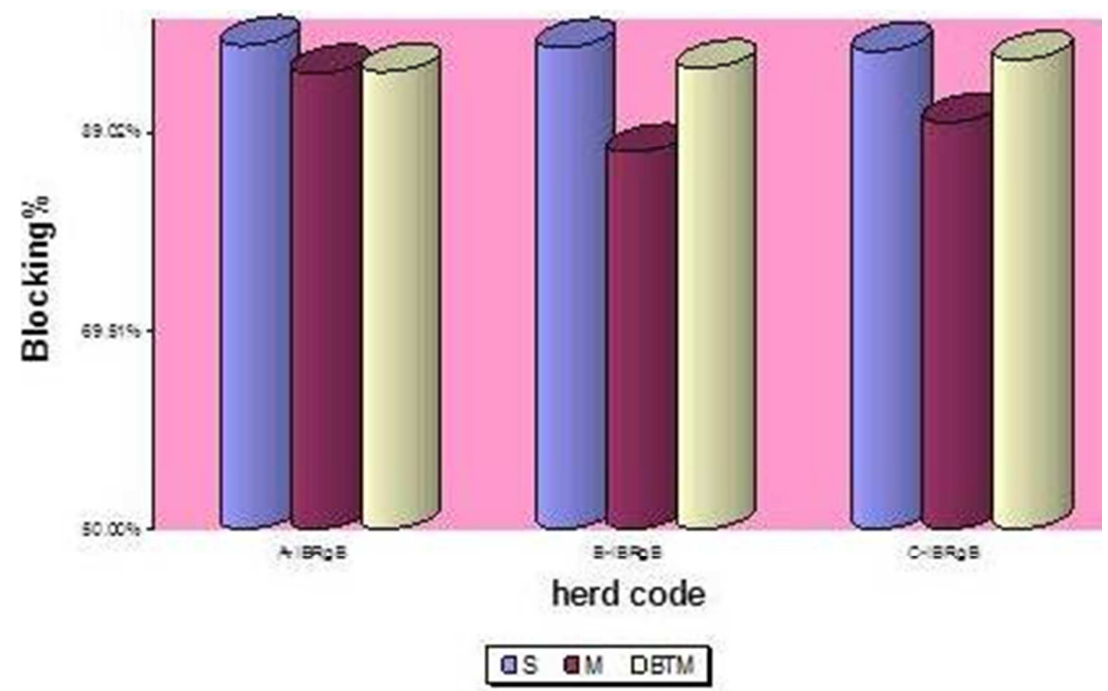

Fig. (2): Mean BHV1 Blocking Percent in the Three Farms in Different Kinds of Samples, as Assessed by IBR Gb Test Kit 


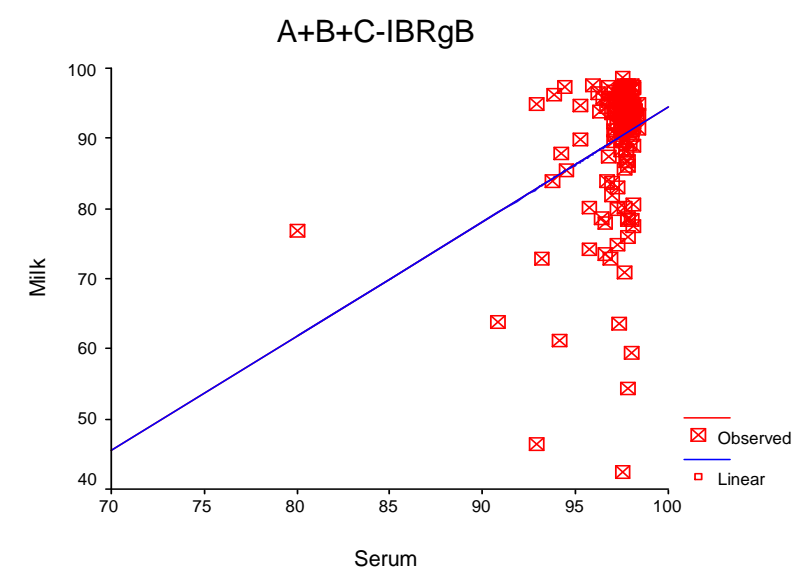

Fig. (3): Correlation between BHV-1 Blocking Percentage in Individual Serum and Milk Samples at the Three Farms

$\mathbf{r}=0.300 \quad$ (Pearson correlation is significant at the 0.01 level).

F significance $=0.000$

\section{BHV1:}

BHV1 antibody response of individual serum, milk and BTM samples resulting from systemic vaccination in the three farms using indirect ELISA is presented in
Table (2) and illustrated in Figures (4) and (5). Regression, correlation coefficient and F test significance between BHV1 antibody titer in individual serum and corresponding milk samples at the three farms are presented in Figure (6).

Table (2): BHV1 Antibody Response in Individual Serum, Milk and BTM Samples Collected from the Three Farmsa Assessed by ELISA

\begin{tabular}{|l|l|l|l|l|l|}
\hline Farm & Serum (S) & SE & Individual milk(M) & SE & B.T.M. \\
\hline A & 90.9 & 1.99 & 37.8 & 1.47 & 32.0 \\
\hline B & 83.5 & 2.14 & 50.6 & 1.45 & 58.3 \\
\hline C & 69.5 & 2.20 & 44.0 & 1.59 & 59.0 \\
\hline
\end{tabular}

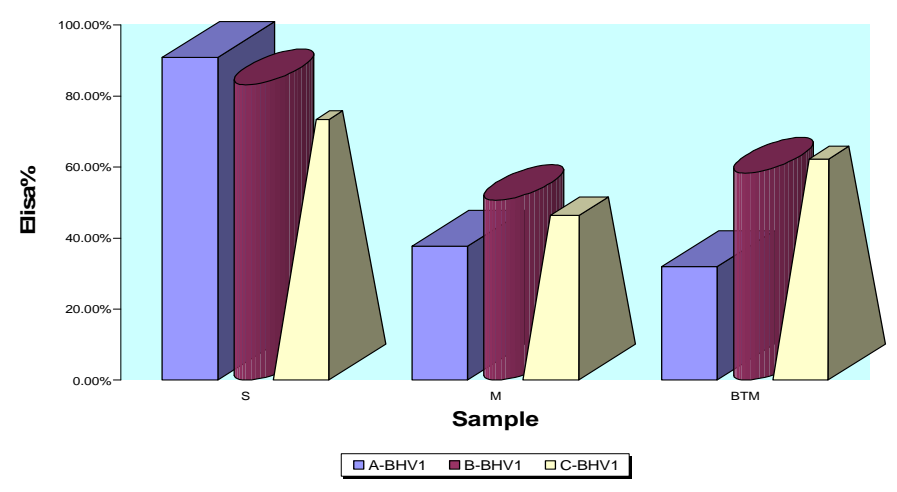

Fig. (4): Mean BHV1 Antibody Response in Different Sources of Samples Collected from the Three Farms, as Assessed ay Indirect ELISA 


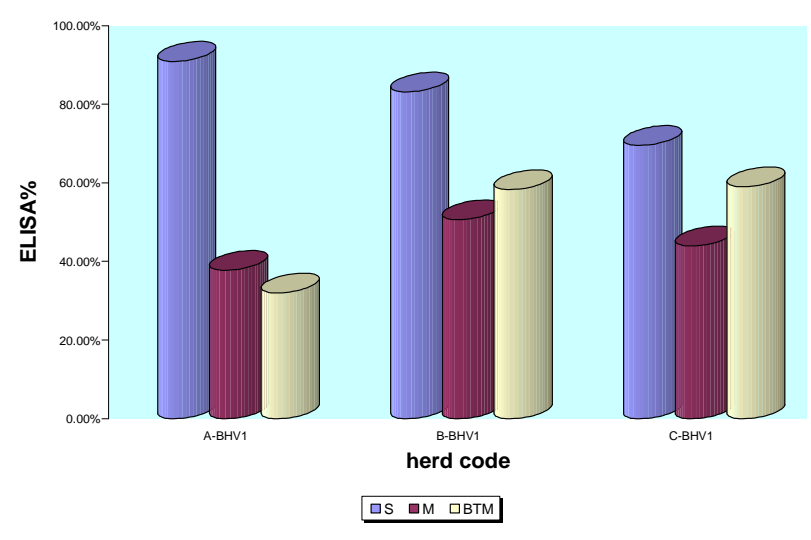

Fig. (5): Mean BHV1 Antibody Response in the Three Farms, as Assessed by Indirect ELISA

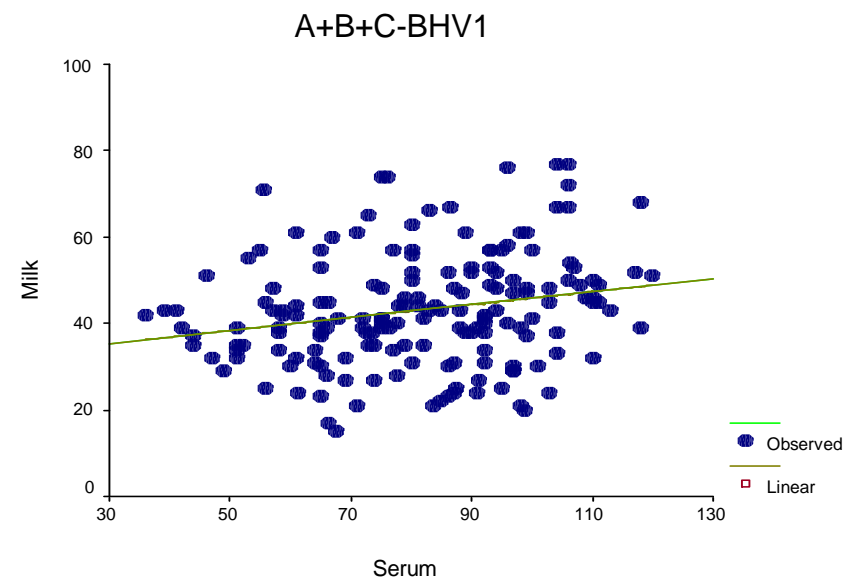

Fig. (6): Correlation between BHV-1 Antibody Titer in Individual Serum and Milk Samples at the Three Farms

$\mathbf{r}=0.220 \quad$ (Pearson correlation is significant at the 0.01 level).

\section{F significance $=0.009$}

Regression, Correlation and $\mathrm{F}$ significance between IBRgB and BHV-1 antibody titer in individual serum and milk samples is presented in Figure (7) and (8) respectively. Figures show high significant correlation and regression coefficient obtained overall between serum and milk samples of all farms. 


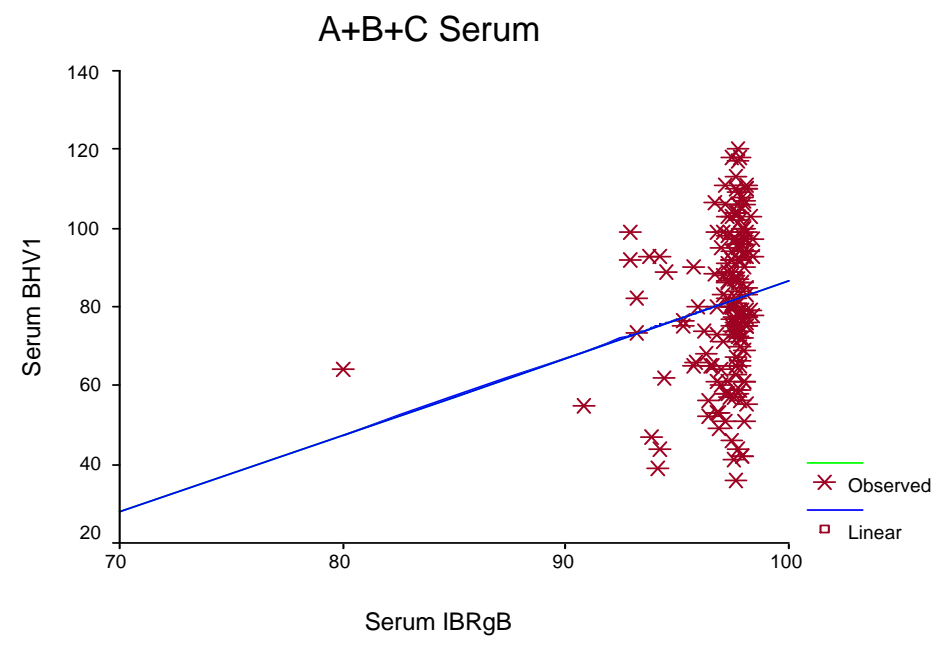

Fig. (7): Correlation between Ibrgb and BHV-1 Antibody Titer in Individual Serum Samples at All Farms

$\mathbf{r}=0.185$ (Pearson correlation is significant at the 0.01 level).

F significance $=0.018$

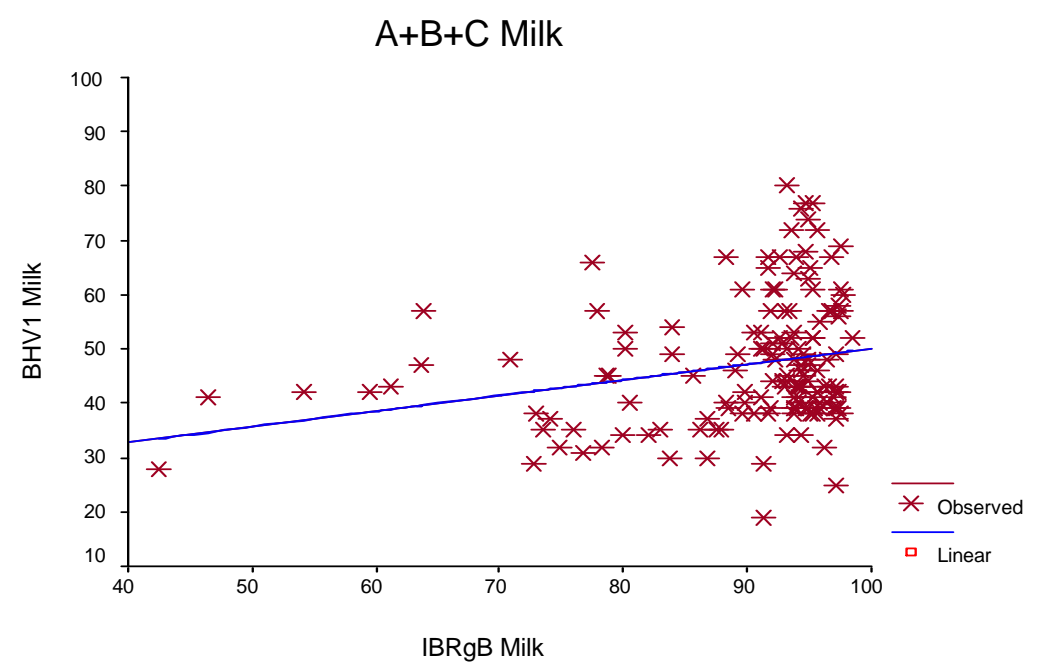

Fig. (8): Correlation between Ibrgb and BHV-1 Antibody Titer in Individual Milk Samples at All Farms

$\mathbf{r}=0.242 \quad$ (Pearson correlation is significant at the 0.01 level)

F significance $=0.003$

\section{BVD:}

BVD antibody response of individual serum, milk and BTM samples resulting from systemic vaccination in the three farms using indirect ELISA is presented in
Table (3) and illustrated in Figures (9) and (10). Regression, correlation coefficient and $F$ test significance between BVD antibody titer in individual serum and corresponding milk samples at the three farms are presented in Figure (11). 
Table (3): BVD Antibody Response in Individual Serum, Milk and BTM Samples Collected from the Three Farms as Assessed by ELISA

\begin{tabular}{|l|l|l|l|l|l|}
\hline Farm & Serum (S) & SE & Individual milk (M) & SE & B.T.M. \\
\hline A & 83.3 & 2.13 & 72.2 & 1.69 & 72.4 \\
\hline B & 96.5 & 1.76 & 70.3 & 1.32 & 77.8 \\
\hline C & 85.8 & 2.17 & 52.1 & 1.79 & 53.8 \\
\hline
\end{tabular}

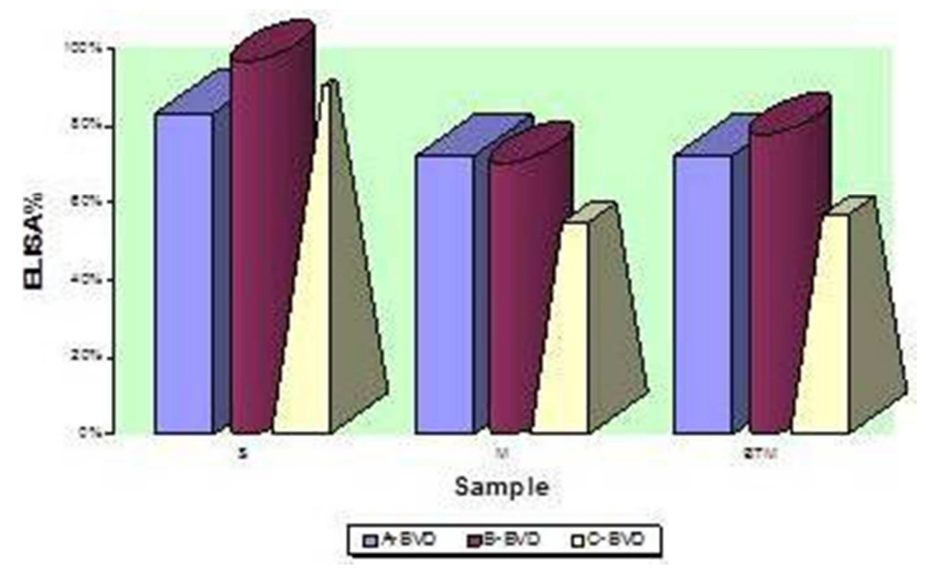

Fig. (9): Mean BVD Antibody Response in Different Sources of Samples Collected from the Three Farms, as Assessed by Indirect ELISA

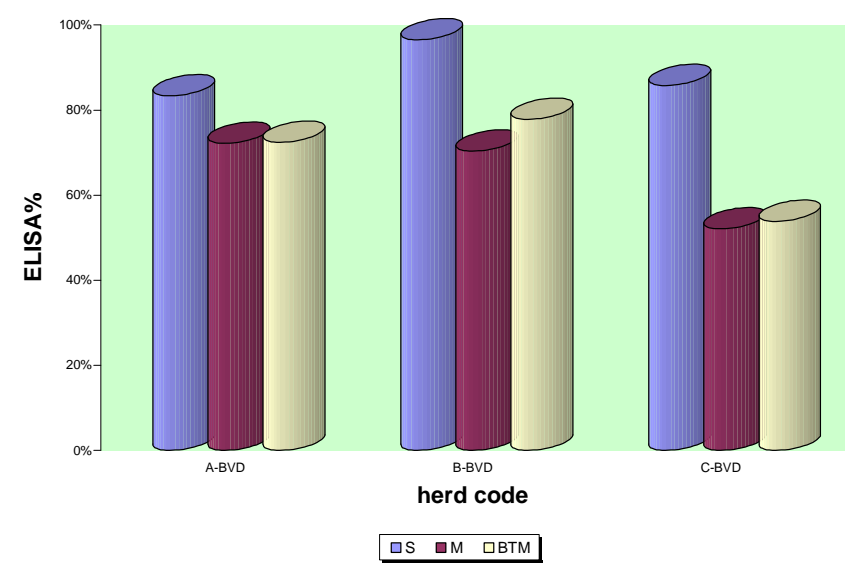

Fig. (10): Mean BVD Antibody Response in the Three Farms, as Assessed by Indirect ELISA 


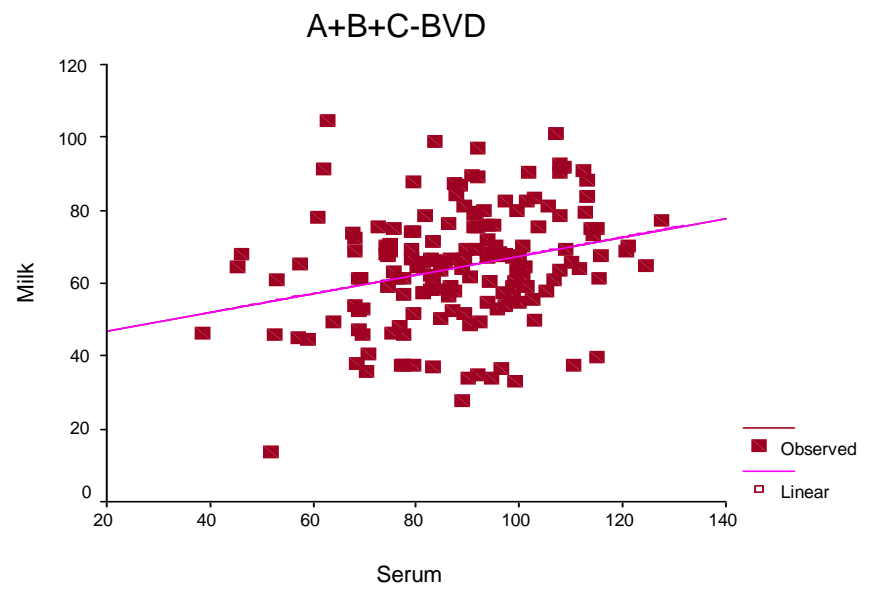

Fig. (11): Correlation between BVD Antibody Titer in Individual Serum and Milk Samples at the Three Farms

$\mathbf{r}=0.273 \quad$ (Pearson correlation is significant at the 0.01 level).

F significance $=0.001$

Regression, correlation coefficient and $\mathrm{F}$ test significance between IBRgB antibody blocking percent, BHV1 and BVD antibody titer in individual serum and corresponding milk samples show high significant correlation and regression coefficient obtained overall between serum and milk samples.

\section{Discussion}

In ruminants, immunoglobulins predominantly of the IgG class, are selectively transported from the maternal circulation into the mammary secretions before parturition, ready for ingestion and absorption in colostrum by the suckling neonate Husband (1998). The bovine transfers large amount of IgG immunoglobulins, from the blood stream across the mammary barrier into colostrum and milk by a specific transport mechanism larson et al (1980). Although antibody concentrations are generally lower in milk than sera, equivalent test sensitivity can be achieved by using different cut-off values or different test dilutions Pritchard et al (2002).

The present study was designed to evaluate the vaccination programs in different commercial dairy farms at three different provinces in Egypt, a number of different vaccination and management strategies were adopted in each herd. Antibody titers in the three herds against glycoprotein B of BHV-1 Virus using IBRgB test kit (IDEXX Laboratories), indirect ELISA test for the detection of specific antibodies against local vaccine strain (Abu Hammad strain) of BHV1, indirect ELISA test for the detection of specific antibodies directed against local vaccine strain (Iman strain) of BVD VIRUS were illustrated and compared in serum, individual milk and bulk tank milk samples.

Serum monoclonal antibody titer against glycoprotein B of BHV1 virus in different herds indicate that all sampled animals responded to vaccination properly with high individual protection level. Coincidently titers in corresponding individual milk samples revealed a high titer in all examined herds as well as serum samples. Measuring IBRgB blocking percent in BTM samples which had been collected at the same time of individual serum and milk samples collection showed an antibody titer higher than or close to those measured in individual milk samples, indicating that the Herd Protection level (HPL) is sufficient for BHV1 vaccination. The present study revealed that, the IBRgB 
antibody titer in BTM may permit an adequate determination of immune status of the herd for large scale epizotiological studies. This result was in harmony with those obtained by De Wit et al (1998), Van Wuijckhuise et al (1998), Banks et al (2000) and Kramps et al (2004).

Statistical analysis showed high regression, correlation coefficient (significant at 0.01 level) and $F$ test significance $(r<0.05)$ between IBRgB antibody blocking percent in individual serum and corresponding milk samples, so milk could replace serum into measuring antibodies against glycoprotein B of BHV1 virus to evaluate the immune status of dairy animal, this result was in harmony with those obtained by Nylin et al (2000), Truyen et al (2003) and Kramps et al (2004).

Serum antibody titer against BHV1 virus measured with indirect ELISA revealed a high antibody titer indicating that all sampled animals responded to vaccination properly with high individual protection level this finding concur with the work of Cho and Bohac (1985), Kramps et al (1993), Odendaal et al (1997), Graham et al (1998), Samira et al (2001) and Alvarez et al (2007). Coincidently titers in corresponding individual milk samples revealed a high titer in all examined farms as well as serum samples, this finding coincide with that of Wellenberg et al (1998), Tekes et al (1999) and Ghazy et al (2007).

Measuring BHV1 ELISA percent in BTM samples showed an antibody titer higher than or close to those measured in individual milk samples titer, indicating that the HPL is sufficient for BHV1 vaccination. The BHV1antibody titer in BTM may permit an adequate determination of immune status of the herd for large scale epizotiological studies. This result is in agreement with those obtained by Frankena et al (1997), Paton et al (1998), Nylin et al (2000), Banks et al (2000), Straub (2001), Stahl et al (2002) and Pritchard et al (2003).

Statistical analysis showed high regression, correlation coefficient (significant at 0.01 level) and $\mathrm{F}$ test significance $(\mathrm{r}<0.05)$ between BHV1 antibody titer in individual serum and corresponding milk samples, indicating a close agreement between antibody titers in serum and skim milk samples, this result was in harmony with those obtained by Wellenberg et al (1998) Graham et al (1998) and Tekes et al (1999).

Relation between IBRgB blocking ELISA and BHV1 indirect ELISA test results in serum and milk samples were analyzed statistically, a high regression, correlation coefficient (significant at 0.01 level) and $\mathrm{F}$ test significance $(\mathrm{r}<0.05)$ between both tests in serum and milk samples were recognized. IgB blocking ELISA and indirect ELISA tests performed equally well indicating the in-house developed BHV1 antibody ELISA is significant into monitoring antibody level of both samples. Similar results were obtained by Truyen et al (2003) and Kramps et al (2004).

Serum antibody titer against BVD virus was measured in each herd using indirect ELISA revealed a high antibody titer indicating that all sampled animals responded to vaccination properly with high individual protection level. Statistical analysis showed high regression, correlation coefficient (significant at 0.01 level) and $F$ test significance $(\mathrm{r}<0.05)$ obtained overall between BVD antibody titer in individual serum and corresponding milk samples, milk could replace serum into measuring antibodies BVD virus to evaluate the immune status of dairy animal, this result was in harmony with those obtained by Niskanen et al (1989) and Niskanen et al (1991).

Measuring BVD ELISA percent in BTM samples showed an antibody titer higher than or close to those measured in individual milk samples, indicating that the (HPL) is sufficient for BVD vaccination. The BVD antibody titer in BTM may permit an adequate determination of immune status of the herd for large scale epizotiological studies, similar results were obtained by Niskanen et al (1991) Niskanen (1993) Rossmanith and Deinhofer (1998) Paton et al (1998) Kramps et al (1999) Graham et al (2001) Beaudeau et al (2001) Stahl et al 
(2002), Melendez and Donovan (2003) and Bottcher et al (2003). Routine vaccination for BVD, suspicion of BVD, housing of pregnant cows with calves, total number of cows and the proportion of cows that were dry were all associated with increased BVD VIRUS antibodies in bulk milk Humphry et al (2012).

Comparing of antibody titers against IBRgB in the three herds showed no significant difference of IBRgB blocking percent between the three herds. While, Comparing of antibody titers against BHV1 using indirect ELISA in the three herds showed that, the greatest value of BHV1 serum antibody titer was recorded in farm "A", little bit more than farm "B", then farm " $\mathrm{C}$ ". While in individual milk samples the high prevalence was recorded in farm "B", and the lesser extent was in farm "A". The different results between IBRgB and BHV1 indirect ELISAs may be explained by differences in antibody isotype or antibody avidities in milk as compared with serum, or by incompatability of the blocking-test principle with milk samples, same results were obtained by Kramps et al (2004).

Comparing of antibody titers against BVD in the three herds showed that, the greatest value of BVD serum antibody titer was recorded in farm "B", more than farm " $\mathrm{C}$ " and "A" which have no significant difference between each other. While in milk samples the high prevalence was recorded in farm " $A$ " with no significant difference with farm "B", and the lesser extent was in farm " $\mathrm{C}$ ". The effectiveness of vaccination and immunoglobulin concentration in milk may be influenced by several factors during lactation, the level of antibodies in milk showed an inverse relationship to the amount of milk produced Niskanen et al (1989), acute inflammation and infection status of the mammary gland and some physiological factors such as the number and stage of lactation Caffin et al (1983), stressful conditions and corticosteroid treatment Pastoret et al (1982) impaired selective transport of IgG in milk.

In conclusion, this work demonstrates that, the described ELISA's for BHV1and BVD were found to be an effective procedure in both samples (serum and milk). It involved simple techniques, and produced results at least equivalent to the standard SNT with considerable savings in time and labor. The milk tests were robust, straightforward to perform, and suitable for routine veterinary diagnostic use as an alternative to sera in lactating animals, but standardization and harmonization of milk samples should be a continuous effort for the detection of antibodies against local vaccine strains for evaluation of vaccination strategy in Egypt. Results also indicate that both "pneumo 3" vaccine used in both herds "A" and "B" and "Cattle Master 4" vaccine used in herd " $C$ " are highly effective in producing immunization against BHV-1 and BVD infection.

\section{Acknowledgment}

This study was supported by Faculty of Veterinary Medicine, Cairo University and National Research Center, Cairo, Egypt, and it was a part of Ph.D. thesis prepared by Mohamed Karam El-Bayoumy.

\section{References}

Abd EL-Razik, K. A., Ghazi, Y. A. \& Salama, E. M. (2007). "Monitoring of Brucella Reactor does Following Milk Examination Using Different Techniques," Pakistan Journal of Biological Sciences, 10 (2) 240-244.

Alvarez, M., Donate, J. \& Makoschey, B. (2012). "Antibody Responses Against NonStructural Protein 3 of Bovine Viral Diarrhea Virus in Milk and Serum Samples from Animals Immunised with an Inactivated Vaccine," Vet. J., 191(3) 371376.

Alvarez, M., Munoz Bielsa, J., Santos, L. \& Makoschey, B. (2007). "Compatibility of a Live Infectious Bovine Rhinotraheitis (IBR) Marker Vaccine and an Inactivated Bovine Viral Diarrhea Virus (BVDV) Vaccine," Vaccine, (25) 6613-6617.

Armstrong, R. M. (1997). "Development of Tests for Antibodies against Foot-andMouth Disease Virus in Cattle Milk," J. Virol. Methods 63(1-2) 175-180. 
Ata, A., Kale, M., Yavru, S., Bulut, 0. \& Buyukyoruk, U. (2006). "The Effect of Subclinical Bovine Herpesvirus 1 Infection on Fertility of Cows and Heifers," Acta Veterinaria (Beograd), 56 (2-3) 267-273.

Baker, J. C. (1987). "Bovine Viral Diarrhea Virus: A Review," J. Am. Vet. Med. Ass., 190, 1449-1458.

Banks, M., Beer, M., Schuller, W., Thiry, E., Van Oirschot, J. \& Vanopdenbosch, E. (2000). 'Report on Bovine Herpesvirus 1 (BHV 1) Marker Vaccines and the Accompanying Diagnostic Tests,' Scientific Committee on Animal Health and Animal Welfare, 25 October (2000).

Beaudeau, F., Belloc, C., Seegers, H., Assie, S., Pourquier, P. \& Joly, A. (2001). "Informative Value of an Indirect EnzymeLinked Immunosorbent Assay (ELISA) for the Detection of Bovine Viral Diarrhea Virus (BVDV) Antibodies in Milk," J. Vet. Med. B Infect. Dis. Vet. Public Health, 48(9) 705-712.

Bottcher, J., Meier, N., Engel, K. H., Grummer, B. \& Truyen, U. (2003). "Feasibility of Serological Bulk Milk Testing as a Method for BVD Surveillance," Berl. Munch. Tierarztl. Wochenschr.,116(5-6) 244-251.

Cho, H. J. \& Bohac, J. G. (1985). "Sensitivity and Specificity of an Enzyme-Linked Immunosorbent Assay for the Detection of Infectious Bovine Rhinotracheitis Viral Antibody in Cattle," Can. J. Comp. Med. 49(2) 189-194.

De Wit, J. J., Hage, J. J., Brinkhof, J. M. A. \& Westenbrink, F. (1998). "A Comparative Study of Serological Tests for Use in the Bovine Herpesvirus 1 Eradication Program in the Netherlands," Vet. Microbiol., 61, 153-163.

Dhenninm, L., Labie, J. \& Gicquel, B. (1979). 'Recherche Sur Les Anticorps Anti O Aphteux Contenus Dans Le Lait De Vachs Vaccines,' Bull. Acad. Vet. France, 52, 513521.
Durham, P. J. K. \& Hassard, L. E. (1990). "An Enzyme-Linked Immunosorbent Assay (ELISA) for Antibodies to Bovine Viral Diarrhea Virus," Vet. Microbiol., 22(1) 1-10.

Edwards, S., Chasey, D. \& White, H. (1983). "Experimental Infectious Bovine Rhinotracheitis: Comparison of Four Antigen Detection Methods," Res. Vet. Sci., 34, 42-45.

Edwards, S. \& Roeder, P. L. (1983). "Attempted Reactivation of Latent Bovine Herpesvirus 1 Infection in Calves by Infection with Ruminant Pestiviruses," Vet. Microbiol., 8(6) 563-569.

Edwards, S., Woods, S. B., Westcott, D. G., Emmerson, M., Jones, P. C. \& Phillips, A. J. (1986). "An Evaluation of Five Serological Tests for the Detection of Antibody to Bovine Herpesvirus 1 in Vaccinated and Experimentally Infected Cattle," Res. Vet. Sci., 41(3) 378-382.

Elvander, M., Edwards, S., Naslund, I. S. \& Linde, N. (1995). "Evaluation and Application of an Indirect ELISA for the Detection of Antibodies to Bovine Respiratory Syncytial Virus in Milk, Bulk Milk and Serum," J. Vet. Diag. Invest., 7 177182.

Entrican, G., Dand, A. \& Nettleton, P. F. (1995). "A Double Monoclonal Antibody ELISA for Detecting Pestivirus Antigen in Blood of Viraemic Cattle and Sheep," Vet. Microbiol., (43) 65-74.

Frankena, K., Franken, P., Vandehoek, J., Koskamp, G. \& Kramps, J. A. (1997). "Probability of Detecting Antibodies to Bovine Herpesvirus 1 in Bulk Milk after the Introduction of a Positive Animal on to a Negative Farm," Ve.T Rec. 140(4) 90-92.

Florent, G. \& De Maneffe, C. (1986). "Enzyme Linked Immunosorbent Assay Used to Monitor Serum Antibodies to Bovine Respiratory Disease Viruses," Vet. Microbiol., 11 309-317. 
Ghazy, A. A., Ahmed, W. M., Mahmoud, M. A. \& Ahmed, A. Lamia (2007). 'Prevalence of Infectious Bovine Rhinotracheitis and Bovine Viral Diarrhea Viruses in Female Buffaloes with Reproductive Disorders and Parasitic Infections,' Int. J.of Dairy Sci., 2 (4) 339-347.

Graham, D. A., German, A., Mclaren, I. E. \& Fitzpatrick, D. A. (2001). "Testing of Bulk Tank Milk from Northern Ireland Dairy Herds for Viral RNA and Antibody to Bovine Viral Diarrhea Virus," Vet. Rec., 149(9) 261-265.

Graham, D. A., Mcshane, J., Mawhinney, K. A., Mclaren, I. E., Adair, B. M. \& Merza, M. (1998). "Evaluation of a Single Dilution ELISA System for Detection of Seroconversion to Bovine Viral Diarrhea Virus, Bovine Respiratory Syncytial Virus, Parainfluenza-3 Virus, and Infectious Bovine Rhinotracheitis Virus: Comparison with Testing by Virus Neutralization and Hemagglutination Inhibition," J. Vet. Diagn. Invest., 10(1) 43-48.

Humphry, R. W., Brulisauer, F., Mckendrick, I. J., Nettleton, P. F. \& Gunn, G. J. (2012). "Prevalence of Antibodies to Bovine Viral Diarrhoea Virus in Bulk Tank Milk and Associated Risk Factors in Scottish Dairy Herds," Vet. Rec., Nov 3; 171(18):445.

Husband, A. (1998). 'Passive Transfer of Immunity. In Immunology of Cattle,' Handbook of Vertebrate Immunology," Eds P-P. Pastoret, Griebel P., Bazin H. and Govaerts A. San Diego, Academic Press. PP 464-466.

Kale, M., Ata, A., Yavru, S., Yapkic, O., Bulut, O. \& Gulay, M. S. (2006). "The Effect of Infection with Bovine Viral Diarrhea Virus on the Fertility of Cows and Heifers," Acta Veterinaria (Beograd), 56 (5-6) 467-477.

Kale, M., Yavru, S., Ata, A., Kocamuftuoglu, M., Yapici, O. \& Hasircioglu, S. (2011). "Bovine Viral Diarrhoea Virus (BVDV) Infection in Relation to Fertility in Heifers," Journal of Veterinary Medical Science, 73, 3, 331-336.
Kramps, J. A., Banks, M., Beer, M., Kerkhofs, P., Perrin, M., Wellenberg, G. J. \& Van Oirschot, T. J. (2004). "Evaluation of Tests for Antibodies against Bovine Herpesvirus 1 Performed in National Reference Laboratories in Europe," Veterinary Microbiology 102 169-181.

Kramps, J. A., Quak, S., Weerdmeester, K. \& Van Oirschot, J. T. (1993). "Comparative Study on Sixteen Enzyme-Linked Immunosorbent Assays for the Detection of Antibodies to Bovine Herpesvirus 1 In Cattle," Vet. Microbiol. 35(1-2) 11-21.

Kramps, J. A., Van Maanen, C., Van De Wetering, G., Stienstra, G., Quak, S., Brinkhof, J., Ronsholt, L. \& Nylin, B. (1999). "A Simple, Rapid and Reliable EnzymeLinked Immunosorbent Assay for the Detection of Bovine Virus Diarrhea Virus (BVDV) Specific Antibodies in Cattle Serum, Plasma and Bulk Milk," Vet. Microbiol., 64(2-3) 135-144.

Larson, B. L., Heary, H. L. \& Devery, J. E. (1980). "Immunoglobulin Production and Transport by the Mammary Gland," J. Dairy Sci. 63 665-671.

Lecomte, C., Pin, J. J., De Moerlooze, L., Vandenbergh, D., Lambert, A. F., Pastoret, P. P. \& Chappius, G. (1990). "ELISA Detection of Bovine Viral Diarrhea Virus Specific Antibodies Using Recombinant Antigen and Monoclonal Antibodies," Vet. Microbiol., (23) 193-201.

Melendez, P. \& Donovan, A. (2003). "HerdLevel ELISA Seroprevalence of Bovine Viral Diarrhea Antibodies in Bulk-Tank Milk in Chilean Dairy Herds," Prev. Vet. Med. 60(3) 237-341.

Mohamed, N. A., Hussein, H. A., Mohamed F. M. \& Shalaby, M. A. (2005). 'Isolation, Antigenic and Molecular Characterization of Bovine Viral Diarrhea Virus Field Strains from Apparently Health Buffaloes in Egypt,' Int. J. Of Virology, 1(1) 42-48. 
Mohanty, S. B. \& Lillie, M. G. (1965). "A Quantitative Study of the Infectious Bovine Rhinotracheitis Neutralization Test," Amer. J. Vet. Res., 26 892-896.

Niskanen, R. (1993). "Relationship between the Levels of Antibodies to Bovine Viral Diarrhea Virus in Bulk Tank Milk and the Prevalence of Cows Exposed to the Virus," Vet. Rec.,133(14) 341-4.

Niskanen, R., Alenius, S., Larsson, B. \& Jacobsson, S. O. (1991). "Determination of Level of Antibodies to Bovine Viral Diarrhea Virus (BVDV) in Bulk Tank Milk as a Tool in the Diagnosis and Prophylaxis of BVDV Infections on Dairy Herds," Arch. Virol., (Supp.3), 245-251.

Niskanen, R., Alenius, S., Larsson, B. \& Juntti, N. (1989). "Evaluation of an EnzymeLinked Immunosorbent Assay for Detection of Antibodies to Bovine Virus Diarrhea Virus in Milk," Zentralbl. Veterinarmed. B. 36(2) 113-118.

Nuotio, L., Neuvonen, E. \& Hyytiainen, M. (2007). "Epidemiology and Eradication of Infectious Bovine Rhinotracheitis/Infectious Pustular Vulvovaginitis (IBR/IPV) Virus in Finland," Acta Vet. Scand., 49:3.

Nylin, B., Stroger, U. \& Ronsholt, L. (2000). "A Retrospective Evaluation of a Bovine Herpesvirus-1 (BHV-1) Antibody ELISA on Bulk-Tank Milk Samples for Classification of the BHV-1 Status of Danish Dairy Herds," Prev. Vet. Med., (47) 91-105.

Odendaal, M. W., Morris, S., Preez, E., Du Aitchison, H. \& Du Preez, E. (1997). "The Humoral Immune Response in Cattle after Immunization with a Multivalent IBR/PI3/Pasteurella Haemolytica A1 Leukotoxin Vaccine," OnderstepoortJournal-of-Veterinary-Research., 64 (3) 205212.

Pastoret, P. P., Thiry, E., Brochier, B. \& Derboven, G. (1982). "Bovid Herpesvirus 1 Infection of Cattle: Pathogenesis, Latency, Consequences of Latency," Ann. Rech. Vet., 13, 221-235.
Paton, D. J., Christiansen, K., Alenius, S., Cranwell, M. P., Pritchard, G. C. \& Drew, T. W. (1998). "Prevalence of Antibodies to Bovine Virus Diarrhea Virus and Other Viruses in Bulk Tank Milk in England and Wales," Vet. Rec.,142(15) 385-91.

Payment, P., Assaf, R., Trudel, M. \& Marois, P. (1979). "Enzyme-Linked Immunosorbent Assay for Serology of Infectious Bovine Rhinotracheitis Virus Infections," J.Clin. Micr. Nov., P.633-636.

Pritchard, G. C., Banks, M. \& Vernon, R. E. (2003). "Subclinical Breakdown with Infectious Bovine Rhinotracheitis Virus Infection in Dairy Herd of High Health Status," Vet. Rec.,153(4) 113-117.

Pritchard, G. C., Kirkwood, G. M. \& Sayers, A. R. (2002). "Detecting Antibodies to Infectious Bovine Rhinotracheitis and BVD Virus Infections Using Milk Samples from Individual Cows," Vet. Record, February 9, 150:6 182-183.

Reed, L. J. \& Muench, A. (1938). "A Simple Method of Estimating Fifty Percent Endpoints," Amer. J. Hyg., 27: 443-445.

Rola, J., Larska, M. \& Polak, M. P. (2005). "Detection of Bovine Herpesvirus1 from an Outbreak of Infectious Bovine Rhinotracheitis," Bull, Vet. Inst. Pulawy, 49, 267-271.

Rossmanith, W. \& Deinhofer, M. (1998). "The Occurrence of BVD Virus Infections in Lower Austrian Dairy Farms," Dtsch. Tierarztl. Wochenschr., 105(9) 346-349.

Samira, S. T., El-Sabbagh, M. M. A., Ghaly, H. M. \& Abdel Samae, M. M. (2001a). 'Production and Evaluation of a Multicomponant Inactivated Respiratory Viral Vaccine [BVDV, IBRV, PI3V and Bovine Adeno Virus Type 3; Pneumo-4] In Cattle,' Egypt. J. Agric. Res., 79 (1) 335-351.

Sandvik, T. (1999). "Laboratory Diagnostic Investigations for Bovine Viral Diarrhea Virus Infections in Cattle," Vet. Microbiol., 64(2-3) 123-134. 
Stahl, K., Rivera, H., Vagsholm, I. \& MorenoLopez, J. (2002). "Bulk Milk Testing for Antibody Seroprevalences to BVDV and BHV-1 in a Rural Region of Peru," Prev. Vet. Med., 56(3) 193-202.

Straub, 0. C. (1991). "BHV1 Infections: Relevance and Spread in Europe," Comp. Immunol. Microbiol. Infect. Dis., (14) 175186.

Straub, 0. C. (2001). "Advances in BHV1 (IBR) Research," Dtsch. Tierarztl. Wochenschr., 108(10) 419-422.

Tekes, L., Markos, B., Kecskemeti, S., Mehesfalvi, J., Mate, Z. \& Kudron, E. (1999). "Prevalence of Bovine Herpesvirus 1 (BHV1) Infection in Hungarian Cattle Herds," Acta Vet. Hung. 47(3) 303-309.

Truyen, U., Isa, G., Gerbermann, H., Bogner, K. H., Banzhaf, K., Kostler, M., Pauels, F. J., Czerny, C. P. \& Wittkowski, G. (2003). "BHV-1 Eradication Program in Bavaria: A Marker-Independent Strategy," Berl. Munch. Tierarztl. Wochenschr., 116(5-6) 197-202.

Van Wuijckhuise, L., Bosch, J., Franken, P., Frankena, K. \& Elbers, A. R. (1998). "Epidemiological Characteristics of Bovine Herpesvirus 1 Infections Determined by Bulk Milk Testing of all Dutch Dairy Herds," Vet. Rec., 142(8) 181-184.

Wellenberg, G. J., Verstraten, E. R. A. M., Mars, M. H. \& Van Oirschot, J. T. (1998). "Detection of Bovine Herpesvirus 1 Glycoprotein E Antibodies in Individual Milk Samples by Enzyme-Linked Immunosorbent Assays," J. Clin. Microbiol., 36(2) 409-413.

Zadnik, T., Klinkon, M., Nemec, M. \& Mesaric, M. (2001). 'The Analysis of Weekly Milk Bulk Tank Components as a Routine Indicator of Herd Health Status,' ISRVMA Vol.56 (2) 2001. 